\title{
On Service Productivity: The Emerging Platforms Perspective
}

\author{
Wei-Tien Hung1, Soe-Tsyr Yuan² \\ ${ }^{1}$ Department of Recreation Management, Shih-Chien University, Kaohsiung Campus, Taiwan \\ ${ }^{2}$ Department of Management Information System, National Chengchi University, Taiwan \\ Email: hungweitien@mail.kh.usc.edu.tw
}

Received 9 March 2014; revised 2 April 2014; accepted 18 April 2014

Copyright (C) 2014 by authors and Scientific Research Publishing Inc.

This work is licensed under the Creative Commons Attribution International License (CC BY). http://creativecommons.org/licenses/by/4.0/

(c) (i) Open Access

\begin{abstract}
Service research is yet looking for potentially effective methods to improve service industries. This study aims to develop a theoretical model for managing and improving service productivity from a macro industrial perspective (instead of a micro firm perspective). Through the meta analysis of surveying existing literature we develop hypotheses to construct a theoretical model for service productivity improvement. Four cases are used to explain, support and justify this proposed model. This model argues that three platform cornerstones of service productivity are to integrate participants (including consumers) to empower them (empowerment), making them adapt to one another (adaption) and sustain development (sustainability) to improve service productivity.
\end{abstract}

\section{Keywords}

Service Dominant Logic, Service Science, Platform, Empowerment, Adaption, Sustainability, Service Productivity

\section{Introduction}

One study pointed out that the service sector significantly affects a country's economic growth [1]. However, most researches focus on functional level rather than macro level which talked about how to improve the productivity of service industry sectors. Furthermore, as Bridges' opinion [2] pointed out, both entrepreneurship and innovation would be the important part of service research. Masso \& Vahter's study [3] which found that the innovations would increase productivity in a service sector also supported Bridges' opinion. Although scholars recognized that the issue of productivity was important, there has not been a method that could be used to improve the innovations and productivity and describe the process of managing productivity improvement. 
Hence, the aim of the study is to propose a theoretical concept, emerging platform, to be a basis of increasing service industries' productivity and construct a framework to describe the process. In this article, the emerging platform means a visible or non-visible platform which could carry the value creation entities, foster cooperations between these entities and drive the progress of productivity of a service system. In addition to the model to describe how an emerging platform works, some implications grounded on the proposed model will also be discussed in the last section.

Although scholars have applied the term of productivity which has been used in manufacturing, and modified its content for the service context [4], there has not been a consistent definition of service productivity among scholars so far. The definition of service productivity was discussed in Section 2. For solving the research question, this study takes two dimensions to address the research problem, which are service science and service dominant logic (SDL). This paper not only combines these two dimensions, but also adopts the value network perspective to propose a framework describing how the approach provided here improves service productivity in the long run. Based on the concept of a value network, the focus of this paper is no longer on a company or organization, but on a value-creating system [5]. Therefore, this paper discusses some characteristics of a valuecreating system during the period of increasing service productivity through an approach for improving the service productivity of a service system.

For understanding the theoretical framework, this paper is organized as follows. The required foundational background is provided in Section 2. The theoretical framework is then proposed in Section 3. In Section 4, four cases are used to demonstrate and explain our theoretical framework, followed by its propositions developed and justified in Section 5. Finally, Section 6 provides the managerial implications and conclusion remarks.

\section{Foundational Background}

The proposed framework is based on some theoretical foundations, such as service dominant logic, service science, service systems and value networks. The contents of these theories are briefly described in this section. Besides briefing these theories, what service productivity means in this paper through a more systematic literature review is clearly identified.

\subsection{Service Dominant Logic}

Service dominant logic (SDL) was proposed by Vargo \& Lusch [6] in 2004. It recognized some changes to Goods dominant logic in the world economies. Service and Goods dominant logics were a set of assumptions for the world in carrying out economic activities. There are three viewpoints proposed by service dominant logic that are the most significant [7]. First, they define a service as a process utilizing the firm's capability to benefit their customers. The competitive advantage is driven by the operant resources not the operand resources. Second, the value is co-created by providers and customers. This means customers would decide whether the service is valuable, and the firm only proposed the value proposition. Third, organizations play integrators to integrate resources to create value. According to the three viewpoints, SDL implied the interactions among firms (firms as integrator) and communications to customers (customer as co-creator) were important for service productivity.

\subsection{Service Science and Service System}

The term service science was proposed in 2004, and is denominated as Service Science, Management and Engineering (SSME) [8]. Hidaka [9] identified three main research issues in service science: 1) service innovation management, 2) technology to improve service productivity, 3) setting the price of services. This research is focused on the first two issues, which are searching for a systematic method to create service innovation and improving service productivity.

Service science adopts service system and system thinking as research perspectives to deal with its research issues. According to the definition of Spohrer et al. [10], a service system is a value co-production configuration of people, technology, other internal and external service systems, and shared information. The system thinking is a thinking framework based on service systems.

Vargo, Maglio \& Akaka [11] also agreed a service system provides insight into value co-creation. The authors argue service systems interacting through service exchange relationships, an emphasized focal point in SDL, can improve the adaptability and survivability of all service systems that integrate resources in the interaction proc- 
ess. Due to SDL contributions from an analytic perspective and service science as an identified research issue, the service system is an appropriate unit of analysis for service productivity and innovation. Researchers have shown the complementarities between SDL and the service system in terms of theory development [12] [13]. The service system is taken as a unit of analysis in this paper.

\subsection{Service Productivity}

This article aims to provide a way to higher the service productivity of a service systems or service industries. However, it is still hard to measure the service productivity. Hence, for a clear definition of "higher service productivity" we review relevant literature and synthesize them to construct indexes to measure the service productivity. These indexes were divided into two levels (micro and macro level) which were further explained below.

Productivity originally meant the ratio of output and input. It is a simple method and very suitable for manufacturing productivity. However, measuring service productivity is more complex. McLaughlin \& Coffey [14] believed services have an inherent problem, intangibility, which causes some difficulties in measuring service productivity including quality, timing of demand and capacity. They also provided some strategies for measuring service productivity and especially emphasized that we cannot ignore the output/input ratio, even the output/input ratio is a traditional way to measure productivity. The output/input ratio signifies the level of efficiency. The other relevant concept is effectiveness, which is denoted as the ability of an organization to achieve its goal [15]. However, effectiveness has different meanings to firms and consumers. In the service era, consumers decide whether firms are effective. Firms tend to utilize resources as inputs for the transformation process, while customers evaluate the service process between service providers and customers [16]. It is obvious the concept of service productivity should consider service quality. McLaughlin \& Coffey [17] and Filiatrault, Harvey \& Chebat [18] also emphasized the role of service quality in service productivity management. Therefore, some scholars think service productivity and service quality should not be dealt with separately. So far, efficiency and effectiveness have been micro-level productivity (firm-level) concepts.

Besides micro-level productivity (efficiency, effectiveness or service quality), service productivity in this paper also covers service innovation, which is a macro-level productivity dimension. Maglio et al. [19] also referred to creating innovation through a service system. They took education, IT service delivery centers, call centers, and patents as examples to support the argument innovation could be improved through analyzing service systems. Innovation has been treated as an engine of economics, so service innovation as a dimension of service productivity should also be considered.

The other dimension of service productivity is the growth of industrial productivity. Based on traditional economic theory, an industry's total supply quantity is accumulated by each individual firm's quantity. Therefore, each individual firm's productivity increase implying an industrial productivity increase could also be inferred. On the other hand, more firms being created increases industrial service productivity, while industrial service innovation may create new business and attract new investment. Therefore, the literature is integrated to list the four dimensions of service productivity mentioned in this paper, which are efficiency, effectiveness, service innovation, and the growth of industrial service productivity. Table 1 compares the productivity dimensions between service and manufacturing.

\subsection{Value Networks}

In the manufacturing age, traditional strategic analysis explains the firms' competitive behavior based on an assumption of the firm as an entity pursuing the maximization of profit or competitive advantage. The value chain was a useful tool at that time [20] [21]. However, in the service economy, the value chain is inappropriate for uncovering sources of value because the products and services became dematerialized [5] [22] [23].

In addition to the products and services being dematerialized, the "network economy" has been recognized as a new competitive reality in recent years [24]. Co-operative behavior is widely seen in an industry [25]. Interfirm relationships are a more and more important focal analysis unit [26]. A group of firms cooperating to propose a value proposition used to be the major way to create value. When a value network perspective is adopted, the focus is not on firms or industries, but a value-creation system. Here, a value-creation system is a synonym for a service system. The service system is more widely applied to many kinds of objects, such as the service process, organization, collaboration among firms, and even the industrial or global ecosystem [27]. Each 
Table 1. Comparison of the productivity issues between service and manufacturing.

\begin{tabular}{|c|c|c|c|}
\hline Dimensions & Service productivity & Manufacturing productivity & Level of similarity \\
\hline Efficiency & Mainly defined by input and output. & Mainly defined by input and output. & High \\
\hline Effectiveness & $\begin{array}{l}\text { Service firms consider not only the organizational purpose, } \\
\text { but also the perception of customers. }\end{array}$ & $\begin{array}{l}\text { Mainly refers to whether the } \\
\text { manufacturing process achieves the } \\
\text { organizational purpose. }\end{array}$ & Low \\
\hline $\begin{array}{l}\text { Innovation } \\
\text { capability }\end{array}$ & $\begin{array}{l}\text { Services are seen as a process, so service improvement } \\
\text { involves other purposes beyond the organizational purpose. It } \\
\text { always improves the customers' perceived value, quality, and } \\
\text { reduces risk through a better service system. }\end{array}$ & $\begin{array}{l}\text { To improve efficiency and } \\
\text { effectiveness in terms of } \\
\text { organizational purpose. }\end{array}$ & Low \\
\hline $\begin{array}{l}\text { Growth of } \\
\text { industrial } \\
\text { productivity }\end{array}$ & $\begin{array}{l}\text { For services, it refers to increasing value creation capability } \\
\text { through not only efficiency and effectiveness, but also } \\
\text { innovation (it involves creating a new business model). }\end{array}$ & $\begin{array}{l}\text { In manufacturing, it always refers to } \\
\text { increasing value creation capability } \\
\text { through efficiency and effectiveness } \\
\text { improvement. }\end{array}$ & Low \\
\hline
\end{tabular}

service system could also be an entity in a higher-level service system, connected to one another by value propositions in a value-creating system [28].

Although the service system and value network are two sides of one coin, they provide different meanings for academic research. The system perspective provides concepts such as boundaries, elements, interactions, inputs, and outputs to use as the basis of service productivity. However, there is a lack of a methodological foundation for interaction analysis in the system perspective. Value network analysis can complement the drawbacks of the system perspective. Hence, in this research, the three important theoretical foundations are SDL, the service science and system, and the value network. The abovementioned theoretical perspectives are particularly treated in this study. Their relative relations are shown in Figure 1, which indicates that the value network perspective is adopted as a methodology to achieve the goal of increasing the service productivity of a service system under a SDL context.

\section{The Theoretical Framework for Higher Service Productivity}

This paper proposes a theoretical platform model featuring the important factors required in designing a better service system for higher service productivity.

\subsection{The Proposed Platform Concept}

A “platform" is a general term in many areas. Nowadays, the term is used to mean many objects in parallel positions interacting with each others to achieve a specific goal. Here, the term "platform" is borrowed to capture the reality of a physical or virtual space in which many entities are grounded, communicating and cooperating with one another to support the development of these entities, and continually changing through structural change and other outside environmental forces.

\subsection{Theoretical Framework}

In terms of the platform, there are three important factors that could be used to manage the platform for higher service productivity. They are empowerment, adaption, and sustainability. Empowerment enhances the ability of each entity through the service system in which they are located. Adaption leads to structural adjustment among entities for reacting to inside and outside forces. Finally, the platform can support an ecosystem to eliminate unqualified entities and attract new blood to achieve sustainability. There are also two important mediators, vitality and diversity, and relationships to connect factors as an integrated mechanism. The theoretical model is shown in Figure 2 and will be described and justified afterwards.

As Figure 2 shows, existing of the emerging platform could impact to some factors of a service system such as policy formation, information liquification, communication cost, transaction cost and others shows in Figure 2. Some of these factors would empower entities in a service system to do things more than what they can do before. Other factors would result in changes of value network. This phenomenon was called adaption in this article. In terms of emerging platform, empowerment and adaption were also the characteristics of the emerging platform. Furthermore, the empowerment and the adaption would lead a service system to sustainability, one of characteristics of emerging platform, through two mediators. 


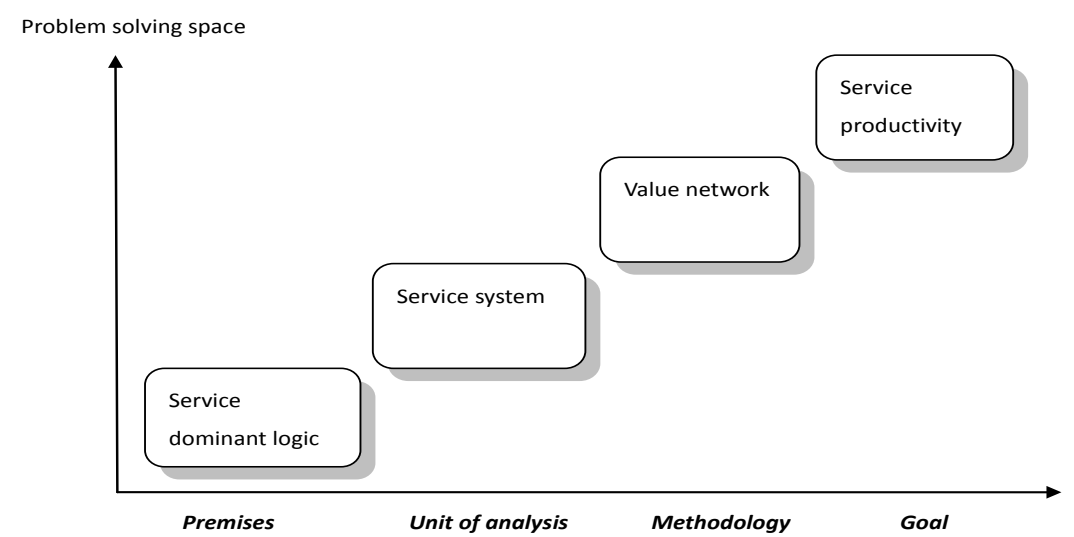

Figure 1. Integrating literature for service productivity.

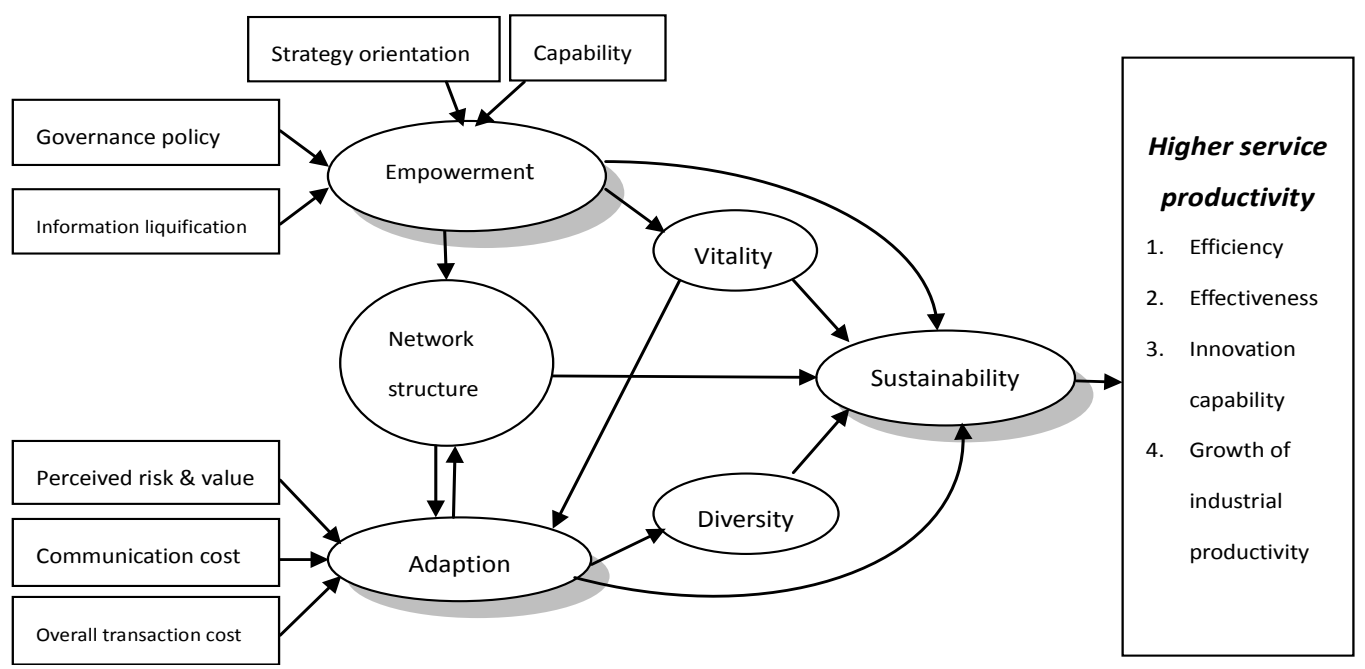

Figure 2. The theoretical model for higher service productivity through the service system platform.

Next section, we provided four mini cases (7-11, eBay, Hollywood and iTune store) to support the validity of the theoretical model. Reasoning of relationships of factors shows in Figure 2 were provided after the discussions of four cases.

\section{Four Cases for Understanding Service Productivity Improvement}

Without loss of generalization, four existing platforms (7-11, eBay, Hollywood and iTunes) are examined to help understand our theoretical framework, of which the verifications are provided in Section 5. This section briefly describes how the cases demonstrate platform management for service productivity.

\subsection{7-11}

7-11 is a convenient chain store founded in USA in 1946. In 1991, a Japanese firm, Ito Yokado, acquired more than half ownership of 7-11 from Southland Corporation, which is the founder company of 7-11. Now, it is the world's largest convenient chain store with owned stores in USA, Japan, Korea, Taiwan and other countries.

7-eleven Japan appears to be a platform creator or integrator. Their important philosophy is “co-existence” with their supplier and local community. 7-eleven Japan employs information systems throughout the entire chain. The information system connects more than 7000 stores and also controls the product distribution strategy. The information technology also contributes to service diversification to realize one of 7-eleven Japan's purposes, which is “self-reformation.” Now, 7-eleven Japan’s business performance has exceeded its parent company (Ito-Yokado Co., Ltd.). 
7-eleven Japan has also played a leadership role in the platform to co-develop new products with food manufacturers. The cooperation relationship built on the platform is based on mutual benefit. For example, manufacturers have an extensive sales force of 7000 chain stores and marketing information from these stores. 7-eleven Japan has increased their ability to develop new products and quickly develop more products at a given cost. Since 1980, 7-eleven Japan has continued to introduce services such as color copying, parcel home-delivery and so on to match their customers' needs. These new services help expand the customer base and bring "incidental shopping” to expand their business.

7-eleven Taiwan is a model using information technology to provide diversified services. "ibon" is a kind of information transformation machine and each 7-eleven store has one "ibon" in Taiwan. Customers could order tickets, clear parking bills, track delivered packages, and print documents or complete other services through a small machine. It is a model that creates value for stakeholders through co-creation (fewer employees needed for 7-11, more services are provided for customers, it is more efficient to complete the transaction for customers, 7-11, and third parties).

The case of 7-eleven Japan and Taiwan provide insights into increasing service productivity. Both 7-eleven Japan and Taiwan play lead roles as integrators of platforms. Through introducing IT technology into their services, they could improve the efficiency and effectiveness of their services. For example, "ibon" in 7-eleven makes several services easy enough to be performed by customers, so a 7-eleven store in Taiwan could perform more services than before with the existing employees and have very few service failures. On the other hand, 7-eleven closely connected their suppliers and benefitted one another by improving their innovation capabilities and reducing market risk. The suppliers could access market information through the powerful channel of 7-eleven. Since they could rapidly introduce new products onto the market, 7-eleven has also benefited from this advance. Today, 7-eleven services in Taiwan cover foods, daily commodities, books and magazines, online games, payment services, ordering tickets, logistics, and telecommunications. More services being completed and more innovation being created also meant a growth in industrial productivity. This demonstrates how stakeholders interact to improve service productivity and co-create wealth for stakeholders, including customers and the overall system.

\section{2. eBay}

eBay is a famous auction website founded in 1995 by Pierre Omidyar in the USA. At first, the website was named auction web, and then it was renamed eBay in 1997. More than 27,000 employees worked in eBay in 2011. Since 1995, the revenue of eBay has increased 17 times. Nowadays, there are more than 500,000 items sold through eBay in the world each day. Total transactions valued at more than 11 billion dollars occur on eBay's platform each year. It is also an international company operating in many countries including, Australia, Canada, German, Hong Kong, India, Taiwan, England, Spain, etc. In 2010, the market value of eBay exceeded 30 billion. Although eBay created a unique business model in its beginning, it also continued to acquire or ally itself with other service companies to upgrade its auction service (i.e. better service, user interface or experience). The sequence of acquisitions and alliances that formed eBay's value network included integrating eStamp, iShip, Mailbox Etc, iEscrow, Billpoint (Billpoint was closed when eBay acquired PayPal in 2002). These related services largely simplified users' transaction process and enhanced the security of the transaction. Along the path of eBay's growth, eBay also rapidly internationalized through foreign acquisition to expand their user base (including buyers and sellers).

In eBay's case, they integrated the operant resources such as third-party service companies, sellers, and buyers into their business value network. These operant resources interacted with one another under eBay's service design and management to create a positive loop in the service system. Rapidly entering foreign markets through acquisition or strategic alliances made their service content widespread, because more sellers meant more items were sold on eBay. More items being sold attracted more buyers due to the abundant choices, which in turn led to more sellers using their service.

On eBay's platform, sellers can access more potential buyers who they could not access before eBay's service was available. Buyers have more choices, which potentially satisfies their need and they could use digital computation to compare products and make the best choice. In this case, the platform empowered sellers and buyers to deal with one another more efficiently (decreasing transaction cost) and create huge transaction volume, which did not occur before eBay's platform was available. Because eBay attracted dealers, other service providers could easily see market opportunities. In sum, eBay created a platform that could facilitate interactions 
among operant resources to increase service productivity from some dimensions such as efficiency, effectiveness, and industrial growth.

\subsection{Hollywood}

Hollywood has been a leader of the movie industry in the global market. Since 1911, the first movie studio was established in Hollywood. During the period of industry development, the industrial scale, structure and business model have largely changed. Industrial scale increased and the industrial structure shifted from vertical integration to networking cooperation. The business model became more diverse (movies were delivered through many channels, for example, DVD, TV or internet).

Even though Hollywood has experienced many changes, its competitive position is still sustained today. One of the reasons for Hollywood's success was a few main movie producers functioned as platforms to lead innovation and integrate the needed resources to propose value propositions. A critical incident in the history of Hollywood was the first animation (Snow White and the Seven Dwarfs) introduced by Disney in 1937. The animation was very successful, successfully opening up a new market (market innovation). The others movie producers were followers in this market. The first animation's success showed the old stories could generate revenue again. This is an example demonstrating the main movies producers could empower existing resources (traditional stories, market, technology), and adapt it to create a service system.

Pixar Animation was also an innovator in creating a new service system. They created a new market (children could also contribute to value creation, stories for children also generated new revenue), and a new venture firm focused on 3D animation also emerged. Related products were constantly introduced to the service system, for example, DVDs, original soundtracks, clothes with the movies on them, and others. In other words, a movie manufacturer adapted other firms to produce these related products to create a part of the value in the system. In sum, there are several main movie manufacturers in Hollywood, also called platforms in this article, acting as an integrator of human resources, scripts, and technologies. Today, even though the revenue from cinema is decreasing, the total production of Hollywood is still growing through the contribution of different channels [29].

\section{4. iTunes Store}

Recently, the music market has experienced a huge change due to Apple introducing the iPod and iTunes onto the digital music market in 2001. Obviously, these innovative services not only changed consumers' behavior in terms of listening to music and experiences, but also increased industrial growth by upgrading the value of music services. At the end of 2011, 16 billions songs had been downloaded from the iTunes store. The iTunes store had a 64\% share of the American market of digital music in 2012. In addition to music, the iTunes store sequentially introduced new digital content categories, for example, books, movies, applications, and TV programs (only for few countries). In 2011, the revenue of the iTunes store reached 7 billion, which is a significant share of Apple's total revenue.

The start point of iTunes was offering an attractive device and a value proposition to their potential users. The value proposition is generated from the combination of product design, iTunes, and an image of a particular lifestyle. The iTunes store bridges the group of content providers to offer customers a deliberate product design. Actually, iTunes combines many operant resources to create this business system, including customers. These operant resources include the design skill, wireless technology, content providers' talent, management skills, users, techniques, and other advanced information technology.

In this case, Apple maintains a workable market (the service system corrected the imperfection of the real market) and a qualified interaction between two sides of content providers and users through deliberate management thinking, advanced information technology, and consumer experience. In the process of system formation, the platform empowers content providers to reach a group of potential customers and rapidly obtain feedback from users. The iPod users are also empowered in terms of their information search capability. Users can easily deal with any content provider, even if they did not know them before. The service system gradually changes through interactions among players, and the players who are new entrants or existing players continually adapt to the changing service system where they were. In the long run, the contents of the service system become more diverse in terms of its structure and attractiveness for potential users. In other words, the service system is dynamic and sustainable through its adaptability. In sum, the iTunes store is also a classic example of a positive loop system that continually grows (i.e. sustainability and service productivity). 


\section{Propositions Development}

\section{1. "Platform" as an Appropriate Theoretical Concept for Service Productivity}

According to SDL, a service is defined as a firm using their capability to benefit others. Further, a service delivering a unique value proposition must be generated through the cooperation of many firms in terms of efficiency and effectiveness considerations, for example, mobile services. As Katz and Shapiro [30] said "many products have little or no value in isolation, but generate value when combined with others”. This statement also describes the nature of a service network. A single service provider may provide less value when it is isolated. Many studies also recognize the value network as an appropriate perspective to analyze the issues of value creation [5] [31]. However, scholars rarely focus on explaining how a value network actually emerges and how a value network grows as a system to achieve long-term sustainability.

From a capability perspective, a firm's competitive advantage comes from its capability which other firms cannot imitate or substitute. This kind of capability is generated by a firm's intangible resources [32] and routine activities [33]. Under the condition of limited resources and the goal of maximizing return, the firm focuses on a specific scope of value activities to generate superior value for target customers or other firms. A service must be completed through the cooperation of a group of firms (i.e. value network or service system). Networking is a fluid structure [34]. Such an organizational structure has an advantage in rapidly responding to the market and consumer taste change in the short term. 7-11, Hollywood, eBay and the iTunes store are good examples of adapting to the market. On the other hand, customers play an important role in value co-creation. Customers' feedback helps firms assess their performance, and then identify performance gaps to improve [35]. To create a sustainable service system, customers should be a part of the service system.

Actually, from an SDL perspective, both customers and firms are a kind of operant resource. Given they are in a service system composed of complex interactions and relationships, the key issues are how the service system emerges and how to achieve and sustain higher service productivity. The four cases showed the emergence of a service system as a platform (hereafter called platform service system) which can facilitate interactions among resources. 7-11, eBay, iTunes, and Hollywood are platforms to support the interaction and integration of resources. Therefore, $\mathrm{P} 1-1$ is proposed.

P1-1: Based on a system thinking approach and SDL, identifying a platform that facilitates interactions among participants in a service value network is an effective approach to improve service productivity.

On a platform, firms and users gather to co-create value. It is argued a platform service system has three characteristics to perform its effective mechanism. These characteristics are empowerment, adaption, and sustainability. Examining the four cases, the first step in changing the status of a service system is to make the participants' ability strong. For example, iTunes and eBay let their content providers access the potential market to decide what contents they should offer. On the other side, consumers are also empowered to influence firms' behaviors and decisions, because the platform improves information distribution. Platform empowerment is defined as increasing the participants’ ability to make better decisions, and then acting to change their cooperation status (i.e. network structure in a service system).

The effect of adaption occurs if empowerment is effective. Hollywood is a good example of the effect of adaption. A movie is produced not only by several firms' co-production, but also depends on the some new firms. For example, for 3D animations and movies introduced in recent years, new service firms specializing in 3D technology emerged soon after. Similar situations also occurred in other cases, such as with 7-11 or eBay. The participants continued adapting to the service system configured by all participants and this would lead to the sustainability of the service system.

P1-2: The platform improves service productivity through its characteristics of empowerment, adaption and sustainability.

\subsection{To Empower All the Participants}

Firms always seek market opportunities to make profits, but some lack the ability to do this, especially the small and medium sized enterprises (SMEs). However, there are two obstacles for firms, especially SMEs. First, SMEs might lack entrepreneurship. The second, as Shane [36] said "entrepreneurs could fail to identify opportunities or identify wrong opportunities”. Some theories of organizational behavior are helpful for firms that cannot act on valuable opportunities. Information gathering plays a key role in organizational behavior [37]. 
Pfeffer and Salancik [38] argued management itself could be considered as information gatherers. Of course, this includes the opportunity search process of an entrepreneur. The "platform" can be seen as an information hub helping participants in a service system to overcome information limitations. Hence, the platform enhances the firms' capability through facilitating information flow to empower the individual firm to do something for value creation. The consumer side is also empowered by the platform. eBay is a typical case of consumer empowerment. Some evidence for empowerment is given in Table 2.

While the participants in a service system are empowered with more ability to adopt actions, the ecological system would also be changed by the actions of the participants based on the new perception generated from their broader vision (it is caused by empowerment).

P2-1: The characteristic of empowerment enables participants in a service value network to initiate network structure changes, and then adapt.

\subsection{How a Platform Empowers Participants}

P2-1 asserted empowerment would motivate network participants to initiate the changes of the system. Here, it is explained why and how empowerment pushes network participants to take actions to adopt the platform. As Chu [39] said, the software was more important than the hardware in a change process. Chu's argument [39] implies changing behaviors are actually driven by the inner factor of an organization, although the hardware is well established. While a platform influence participants internally and externally, it makes participants change behaviors to act on what they need to do, and then the platform demonstrates the characteristic of empowerment. Figure 3 shows a circle of empowerment. Any step could be an initial step of this circle, depending on what kinds of intervention occur in a service system. The next problem is what organizational factors affect their changed behaviors and result in the empowerment of a platform.

\subsubsection{Internal Factors}

Two factors that are altered by a platform, strategy orientation and capabilities, as well as empowering participants to take proactive action to make changes, are considered. Miles and Snow [40] proposed a strategy typology containing four kinds of strategy — defenders, prospectors, analyzers and reactors. Firms adopting prospector strategic orientation continually searched the new marketplace to become "creators of change" [41]. The platform, for example, 7-11, eBay and iTunes, offered a lot of market information to firms connected to the

Table 2. Evidence of a platform empowering participants.

\begin{tabular}{|c|c|c|c|}
\hline Platform & Actions & Who are empowered & The results of empowerment \\
\hline \multirow{4}{*}{$7-11$} & \multirow{4}{*}{$\begin{array}{l}\text { To take on a co-existence philosophy } \\
\text { To build an extensive sale force } \\
\text { To employ information technology } \\
\text { To add DIY services for customers }\end{array}$} & \multirow{4}{*}{$\begin{array}{l}\text { Small service and product } \\
\text { providers } \\
\text { Customers }\end{array}$} & To produce a platform \\
\hline & & & Gaining small firms' accessibility to the \\
\hline & & & \\
\hline & & & $\begin{array}{l}\text { Customers increase their ability to deal with their } \\
\text { daily life }\end{array}$ \\
\hline \multirow{3}{*}{ eBay } & \multirow{3}{*}{$\begin{array}{l}\text { To acquire or ally with other service companies } \\
\text { Using IT technology to facilitate auction } \\
\text { activities } \\
\text { Connecting sellers and buyers with one another }\end{array}$} & ${ }^{\mathrm{S}}$ Small service providers & Small service companies could be connected to the \\
\hline & & Buyers & \\
\hline & & Sellers & $\begin{array}{l}\text { Buyers and sellers could efficiently and effectively } \\
\text { find appropriate dealers }\end{array}$ \\
\hline \multirow{2}{*}{ Hollywood } & $\begin{array}{l}\text { A few main producers bridge the market and } \\
\text { small firms }\end{array}$ & \multirow{2}{*}{$\begin{array}{l}\text { Small service providers } \\
\text { New businesses emerge } \\
\text { (ex, animation studios) }\end{array}$} & $\begin{array}{l}\text { Small service providers could connect to the } \\
\text { demand side through the main producers }\end{array}$ \\
\hline & $\begin{array}{l}\text { A few main producers as integrators of a value } \\
\text { network }\end{array}$ & & $\begin{array}{l}\text { Incremental innovations are continuingly generated } \\
\text { in Hollywood (ex, 3D movies and animation) }\end{array}$ \\
\hline \multirow{4}{*}{ iTunes store } & Collecting anps for iPhone and iPod users & \multirow{3}{*}{ Small service providers } & Attracting more and more content providers \\
\hline & Introducing others to existing content & & Positive loop for content providers and users \\
\hline & esequentially & & Contents are improved quickly \\
\hline & $\begin{array}{l}\text { Creating a simple rule for transactions } \\
\text { Designing a mechanism for rapid feedback }\end{array}$ & Existing content & $\begin{array}{l}\text { The large user base is an advantage for introducing } \\
\text { other existing content } \\
\text { (ex, TV program, open course, etc.) }\end{array}$ \\
\hline
\end{tabular}




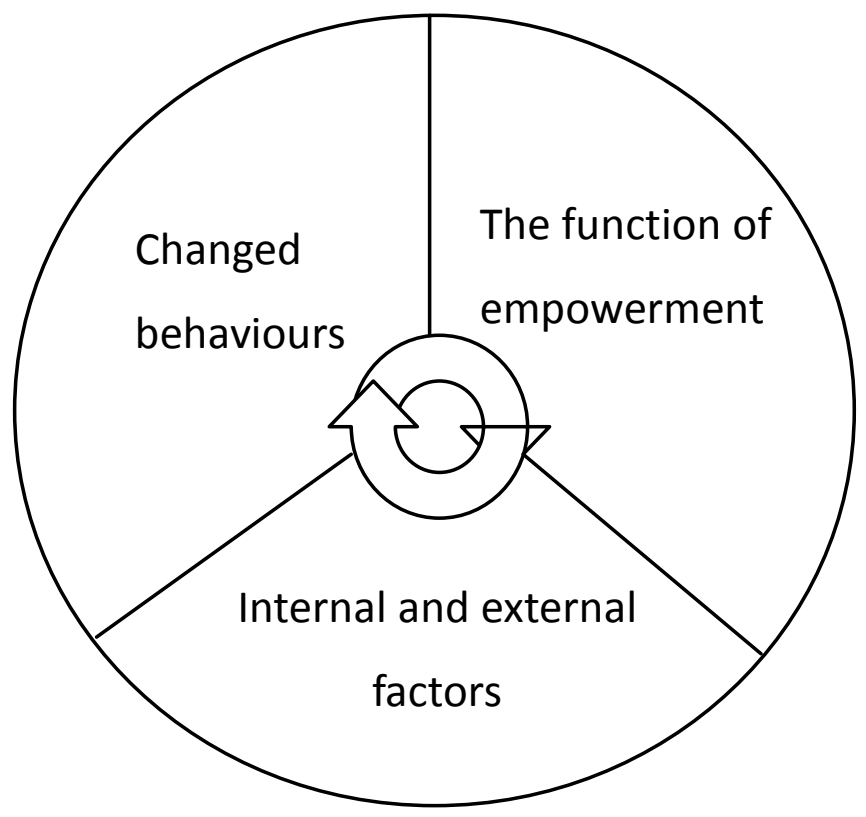

Figure 3. A general model for the function of empowerment.

platform. This information empowered the firms to innovate through taking a prospector strategic orientation. In the strategic research field, the capability means the ability of an organization to exploit the resources it owns [42]. Information is seen as an important resource to firms [43]. Even if the platform could bring market information or insight to the surrounding small firms, the information could not turn into innovations or improvements without the organizational capabilities. For these reasons, the relationships among strategy orientation, capability, the platform, and empowerment are proposed as P2-2.

P2-2: The strategy orientation and capabilities moderate the effect of platform on empowerment for participants in a service system.

\subsubsection{External Factors}

Two factors, governance policy and information liquefaction, externally mediate the impact of the platform in terms of empowerment. A service system needs a governance mechanism. For a service system made up of SMEs, the governance mechanism is much more important, because it helps construct or arrange a network structure for their coordination. However, Huggins \& Johnston [44] mentioned older industries always suffered from path dependence and lock-in (i.e. inertia). Lin \& Zhang [45] suggested a successful network must fit the dynamic requirement of the industry to preserve its competitive advantage. This would hurt firms' competitive advantage in a service system. In general, for SME owners who are rationally bound and ordinary people, adjusting the network structure organically is very difficult unless there is a platform acting as an information facilitator and a network governor, such as with the iTunes store or eBay.

Besides a clear governance policy, information liquefaction is the other external factor influencing firms' ability and intention to make behavioral changes. Normann [28] and Lusch et al. [46] argued organizations could better adapt by being able to liquefy information resources. The information could be liquefied through digital communication, networking, or other more efficient communication tools. If the information is liquefied in a service system, the governance policy would be more efficient and effective. P2-3 is proposed as below.

P2-3: The platform makes the governance policy of a service system clear and makes information liquefying, and then the effect of empowerment is generated.

\subsection{Adaption among the Participants}

As Huggins \& Johnston [44] mentioned, path dependence, lock-in or inertia always appear in older industries. While the environment is stable, the unchanged network could be a source of competitive advantage for the industry and the firms within the industry. Due to information technology, "change" has become normal around 
the world. This is especially the case for services always provided by a group of service firms that are a response to a specific part of the service.

Unlike a manufacturing product, the service industry is always facing a rapidly changing environment, especially the consumers' taste or preference, so the group of service providers should rapidly reorganize their network structure to respond to the changing demand. In sum, the adaption means that the structure of the value network is flexible to adjust to the environmental changes or for seeking improved competitiveness. Table 3 provides evidence from four cases to support proposition P3-1.

P3-1: The characteristic of adaption makes the service value network flexible to adapt to environmental changes. The environmental change (economic, political, social, and technological) implies the optimal structure of the service value network must also be changed. For efficient and effective co-creation, establishing new and renewable inter-participants relationships are critical to a flexible service value network structure.

\subsection{Drivers of Platform's Adaptation}

Why does the platform have the characteristic of adaption? For the basic assumption of the service created by a value network, it implies a platform needs more participants to join and enlarge the potential for service productivity. For this, three major aspects that could be altered by the platform to establish the adaption are proposed. They are subjective evaluation of perceived risk and value, communication and transaction cost. These three drivers were elaborated for establishing three relevant theoretical propositions.

\subsubsection{Driver 1: Perceived Risk and Value}

In general, deciding whether to join a new service value network involves the issue of new business ventures. In terms of ventures, Forlani and Mullins [47] found a significant relationship between perceived risks and venture decisions. According to their research findings, entrepreneurs would not choose ventures with a high degree of variability in their anticipated outcomes. Building a stable and predictable environment is important to attracting new participants.

Given perceived risk (variability) and value (outcome) do matter for new entrants, forming a service value network through platforms such as 7-11, Hollywood or iTunes is a better approach than going into unknown ter-

Table 3. Evidence of a platform empowering participants.

\begin{tabular}{|c|c|c|c|}
\hline Platform & Actions & Who are empowered & The results of empowerment \\
\hline $7-11$ & $\begin{array}{l}\text { Translating market information to small firms. } \\
\text { To connect with their suppliers closely. } \\
\text { Introducing services to enable customer } \\
\text { participation, for example, “ibon” in Taiwan. }\end{array}$ & $\begin{array}{l}\text { Small firms (suppliers) } \\
\text { Customers }\end{array}$ & $\begin{array}{l}\text { To respond to the market quickly. } \\
\text { Shortening the time period of introducing new prod- } \\
\text { ucts. } \\
\text { Broadening the scope of service offerings. } \\
\text { Changing customers' daily behavior. }\end{array}$ \\
\hline eBay & $\begin{array}{l}\text { Creating an organic eco-system for } \\
\text { empowered buyers and sellers } \\
\text { Worldwide replication of the service model }\end{array}$ & $\begin{array}{l}\text { Number of sellers and } \\
\text { buyers } \\
\text { Diversification of } \\
\text { sellers and buyers }\end{array}$ & $\begin{array}{l}\text { Scale of sellers and buyers brought abundant } \\
\text { transaction items into the system. }\end{array}$ \\
\hline Hollywood & $\begin{array}{l}\text { Constructing a movie producers' network } \\
\text { Accessing market information through the main } \\
\text { producers. }\end{array}$ & $\begin{array}{l}\text { Changes to the } \\
\text { eco-system }\end{array}$ & $\begin{array}{l}\text { Emerging new service firms (for example, 3D or } \\
\text { animation studio) to fit the technical requirement of } \\
\text { new movies. } \\
\text { Innovative type of movies (3D or animation). } \\
\text { New type of services, for example, DVDs. }\end{array}$ \\
\hline iTunes store & $\begin{array}{l}\text { Creating a centralized eco-system for } \\
\text { empowered buyers and content providers } \\
\text { To connect the system with popular } \\
\text { devices (iPod and iPhone) }\end{array}$ & $\begin{array}{l}\text { Categories of service } \\
\text { offering } \\
\text { Consumers } \\
\text { Suppliers }\end{array}$ & $\begin{array}{l}\text { Changing consumers’ purchase behaviors. } \\
\text { Changing the distribution system of digital content. } \\
\text { More and more innovative APPs and programs of } \\
\text { good quality appearing. } \\
\text { Bringing new opportunities to create new devices } \\
\text { (iPad). }\end{array}$ \\
\hline
\end{tabular}


ritory or creating and accumulating networks gradually. These platforms provide potential participants with almost perfect information, chances to connect to stakeholders, a well-designed mechanism for building a more stable and predictable environment, and other advantages. The existence of a platform allows more predictable anticipated returns and lower variability. Thus, creating a service value network through platforms effectively decreases perceived risks in attracting potential participants, and then creating more opportunities for the appearance of new services and higher service productivity.

P3-2: The platform could reduce the perceived risks and enhance the value of participating in a service system and fostered its characteristic of adaption.

\subsubsection{Driver 2: Communication Cost}

Bolton and Dewatripont [48] noticed the influence of communication cost on organizational forms. They argued a firm appears to construct a communication network for decreasing communication costs, but the enlarging scale of the organization may offset the communication efficiencies by increasing communication costs. Most cooperation and coordination require a lot of communication to clarify the details of contracts to ensure parties' consensus. A platform could gather relevant firms which were needed for creating a service, for example, the Hollywood files production. A screenwriter could easily find a group of relevant firms for producing a file. Since the communication costs are reduced, then adaption is more likely to occur. A platform introducing IT technology could largely reduce communication costs, as with 7-11, eBay or an iTunes store.

P3-3: The platform could largely reduce communication costs to achieve a high level of performance and efficient interaction to improve the adaption of a service system.

\subsubsection{Driver 3: Overall Transaction Cost}

As mentioned above, attracting more firms to enter the service system and connecting to one another provides opportunities to utilize operant resources to create new services. However, attracting capable firms and renewing the structure of a network always involves uncertainties and risks which would cause losses to adapting firms. From the perspective of organizational economics, the aim of organizational design is minimizing the transaction costs occurring in organizations. Transaction costs refer to the cost of searching for information, coordinating with others, and monitoring and evaluating transactions [49]. Searching for a partner and evaluating if a partner is suitable is a complex process [50]. Higher such costs impede new firms from entry and existing firms from establishing new connections and relationships. A platform could help outside firms save on such transaction costs as entering the service value network and existing firms can establish new cooperation networks.

In terms of the four cases, iTunes offers a well-established and transaction-saving mechanism for the platform owner, APPs providers and consumers. Hollywood also reduces such costs through the main film producers. Like iTunes, eBay also created an efficient and effective environment to reduce the overall transaction cost of the system. 7-11 also demonstrated its ability to be an information hub and coordinator to lead surrounding firms to adapt to changes in customers' tastes and preferences.

P3-4: The platform reduces the overall transaction cost of a network. Transaction cost refers to the searching, bargaining, and evaluation costs due to the uncertainty of transactions.

\subsection{Sustainability of the Service System}

Basically, the term "sustainability" is easy to understand, but it is not easy to conceptualize, measure and formalize [51]. So far, the term of sustainability has referred to ecological and economic dimensions [52]. The purpose of industrial ecology is to evaluate and minimize the impacts from economics activities on the environment [53]. Here, the concept of ecology describing a positive loop in a group of service stakeholders, including the consumer side, is borrowed. Based on a positive development loop [54], the service system could sustain improvement in terms of effectiveness, efficiency, innovation, and industrial growth. Empowerment and adaption as the drivers of sustainability are considered especially in terms of helping firms to face obstacles to innovation [55]. To synthesize the evidence on empowerment and adaption, as shown in Table 2 and Table 3, P4-1 describing the relationships among empowerment, adaption and sustainability is proposed. Some evidence relevant to P4-1 is integrated in Table 4.

P4-1: The characteristic of sustainability, driven by empowerment and adaption, leads to sustainable development of a service ecosystem. 


\subsubsection{Vitality as a Mediator Bridging Empowerment, Adaptation, and Sustainability}

Through empowerment, participants have been made more capable decision makers, but how they implement decisions they have made is still a big problem. It implied that there are a gap between empowerment stage and sustainability stage. The vitality of the service ecosystem is seen as a critical mediator between empowerment and sustainability. Vitality is referred to in the literature as involving urban public design and firm innovation. According to Jalaladdini and Oktay [56], vitality refers to "a safer, more desirable, and more attractive space which has the capacity for offering more choices for social activities as well as being a place for cultural exchanges”. The definition somewhat captures the nature of vitality, including an attractive space, as well as more choices and exchanges. In terms of firm innovation, Gnyawali and Srivastava [57] also advanced the concept of vitality and applied it in the context of a cluster and a network. They referred to the vitality of cluster and network as "the extent to which a cluster is imbued with new knowledge resources over time". In their definition, new knowledge resources are the target measured to evaluate the extent of vitality of a cluster or network. Gnyawali and Srivastava [57] treated it as a catalyst for firm innovation. Gnyawali and Srivastava's definition somewhat echoes the SDL's viewpoint on operant and operand resources. Vitality can be found in the four cases given here. The buyer and sellers on eBay and in the iTunes store actively joined and sought out dealers. The

Table 4. The evidence of a platform helping to achieve sustainability.

\begin{tabular}{|c|c|c|c|c|}
\hline Platform & Empowerment : & adaption conditions & Level & Results in terms of sustainability \\
\hline \multirow{8}{*}{$7-11$} & \multirow{5}{*}{ Empowerment } & \multirow{5}{*}{$\begin{array}{l}\text { Co-existence philosophy } \\
\text { Extensive sale force } \\
\text { Information technology } \\
\text { DIY services for their customers }\end{array}$} & \multirow{5}{*}{ Strong } & \multirow{5}{*}{$\begin{array}{l}\text { 7-11 involves a wide range of services such } \\
\text { as foods, commodities, books, and } \\
\text { telecommunication. } \\
\text { New services emerge continuously. }\end{array}$} \\
\hline & & & & \\
\hline & & & & \\
\hline & & & & \\
\hline & & & & \\
\hline & & Delivering market information to small firms & & $7-11$ is an organic organization which is \\
\hline & Adaption & Connecting to other firms & Middle & always responding to environmental \\
\hline & & Involving customers in the service process & & changes \\
\hline \multirow{4}{*}{ eBay } & \multirow{2}{*}{ Empowerment } & $\begin{array}{l}\text { Cooperation with complementary service } \\
\text { companies }\end{array}$ & \multirow{2}{*}{ Strong } & $\begin{array}{l}\text { Continually internationalizing eBay into } \\
\text { world countries }\end{array}$ \\
\hline & & $\begin{array}{l}\text { Information technology for searching and } \\
\text { auctions }\end{array}$ & & $\begin{array}{l}\text { Business scale is growing in terms of } \\
\text { number of employees, sale items, revenue, } \\
\text { and etc. }\end{array}$ \\
\hline & \multirow[t]{2}{*}{ Adaption } & $\begin{array}{l}\text { Create an organic eco-system for empowered } \\
\text { buyer and sellers }\end{array}$ & \multirow[t]{2}{*}{ Middle } & $\begin{array}{l}\text { Continuously improving auction services } \\
\text { for transaction convenience and safety }\end{array}$ \\
\hline & & Worldwide replication of the service model & & $\begin{array}{l}\text { High turnover rate of sale items to } \\
\text { maintain novelty for users }\end{array}$ \\
\hline \multirow{4}{*}{ Hollywood } & \multirow[t]{2}{*}{ Empov } & \multirow{2}{*}{$\begin{array}{l}\text { Main producers as coordinators and channels } \\
\text { between customer side and supply side } \\
\text { Empowering an old story to create market value }\end{array}$} & \multirow{2}{*}{ Middle } & \multirow{2}{*}{$\begin{array}{l}\text { Keep innovating with movie productions } \\
\text { such as 3D movies and business models } \\
\text { (DVD, original soundtrack, and etc.) }\end{array}$} \\
\hline & & & & \\
\hline & \multirow[b]{2}{*}{ Adaption } & \multicolumn{2}{|l|}{ Constructing a networking for cooperation } & $\begin{array}{l}\text { Being a main player in the global movie } \\
\text { market for a long time }\end{array}$ \\
\hline & & $\begin{array}{l}\text { Accessing market information through main } \\
\text { producers }\end{array}$ & Strong & $\begin{array}{l}\text { New players, for example Pixar Animation } \\
\text { emerged to support innovation in movie } \\
\text { production }\end{array}$ \\
\hline \multirow{7}{*}{ iTunes store } & \multirow{4}{*}{ Empowerment } & Collecting APPs on a platform & \multirow{4}{*}{ Strong } & \\
\hline & & $\begin{array}{l}\text { Enriching the content pool by introducing } \\
\text { others' content. }\end{array}$ & & Accumulation of content \\
\hline & & Information technology & & Upgrading the value of the music service \\
\hline & & A mechanism for rapid feedback from users & & Creating industrial growth \\
\hline & \multirow{3}{*}{ Adaption } & & \multirow{3}{*}{ Strong } & Attracting more and more content creators \\
\hline & & $\begin{array}{l}\text { Creating a centralized eco-system for } \\
\text { empowered buyer and sellers }\end{array}$ & & Enhancing innovation in the APPs market \\
\hline & & Creating a cross-device platform & & \\
\hline
\end{tabular}

\footnotetext{
${ }^{\mathrm{a}}$ The evaluation of the level of empowerment and adaption is based on the results of empowerment and adaption referred to in Table 2 and Table 3.
} 
other unknown auction platforms that eventually disappeared were less active than eBay and the iTunes store. In Hollywood, agents also have to build connections with main producers to seek opportunities to join the movie producer team. The service system of 7-11 contains customers who are part of a service system and have high acceptance of innovation, with a large number of firms. The proposition relevant to the vitality is proposed below.

P4-2: The characteristic of empowerment positively affects adaption and sustainability through the vitality of a service ecosystem.

\subsubsection{Diversity as a Mediator Bridging Adaption to Sustainability}

A service ecosystem should adapt to the environmental changes for achieving a sustainable ecosystem. The change process always involves a term of evolution or progress. Given adaption is defined as the participants in the ecosystem reorganizing their network structure or establishing a new one, how an adaption leads to sustainability remains unknown. To address this, diversity is considered a mediator in this framework. Other scholars in relevant areas agree with this idea. Pirages [58], who discussed the issue of social progress, considered genetic and cultural diversity as important to social progress, because they make people and societies resilient to new challenges.

Scholars studying the issue of business ventures also applied information diversity to explain the relationship between business idea generation and divergent thinking [32]. They found information diversity could positively moderate the impact of divergent thinking on business idea generation. Business idea generation also positively influences venture growth. These two studies point out diversity is crucial for both long-term evolution and short-term creation.

The evidence related to the diversity is easily found from the cases outlined here. The iTunes store, eBay, 7-11 and Hollywood all did well in gathering many buyers, sellers, Apps developers, or SMEs to facilitate the effect of adaption. According to the literature reviewed above and the case evidence, the relationships among adaption, sustainability and diversity as P4-3 is inferred.

P4-3: The characteristic of adaption positively affects sustainability through the diversity of a service ecosystem.

\section{Managerial Implications: Platform Service System Development Strategies}

According to the cases and propositions examined here, a framework was constructed by an ultimate goal, sustainability, and two vectors of empowerment and adaption. The space formed by two vectors was divided into four grids denoting different status service systems. This framework also shows the three strategies to sustainability in Figure 4.

The first strategy is a path going through empowerment and adaption in sequence. The iTunes store and eBay followed this strategy. The second strategy increases their empowerment and adaption at the same time, such as with 7-11. The third strategy demonstrates a path going through adaption and empowerment in sequence, such as with Hollywood. These three strategies are named IT-driven, IT-market-driven, and market-driven, as Figure 4 shows.

The factors of a service system or industry would be changed as our model showed, if a service system or industry employ the emerging platform approach no matter what kind of strategies was be used. However, different strategies have somewhat differences in terms of the path of development progress (as we shows in Figure 4) and the time needed to achieved sustainability and higher service productivity. How the paths of three strategies are different would be explained in next section.

\subsection{IT-Driven Strategy}

The IT-driven path means a platform service system development strategy largely dependent on IT technology. The feature of the strategy follows the steps of 1 . empowerment $\rightarrow 2$. adaption $\rightarrow 3$. sustainability. Sometimes, due to the imperfect market or bounded rationality [59] of humans, solely introducing the IT enables the creation of a platform to facilitate market transactions. For example, eBay and the iTunes store are classic cases of an IT-driven strategy. IT technology helped everyone overcome the bounded rationality of humans to deal with someone in the world. Clearly, eBay and iTunes could not have done this without IT technology. 


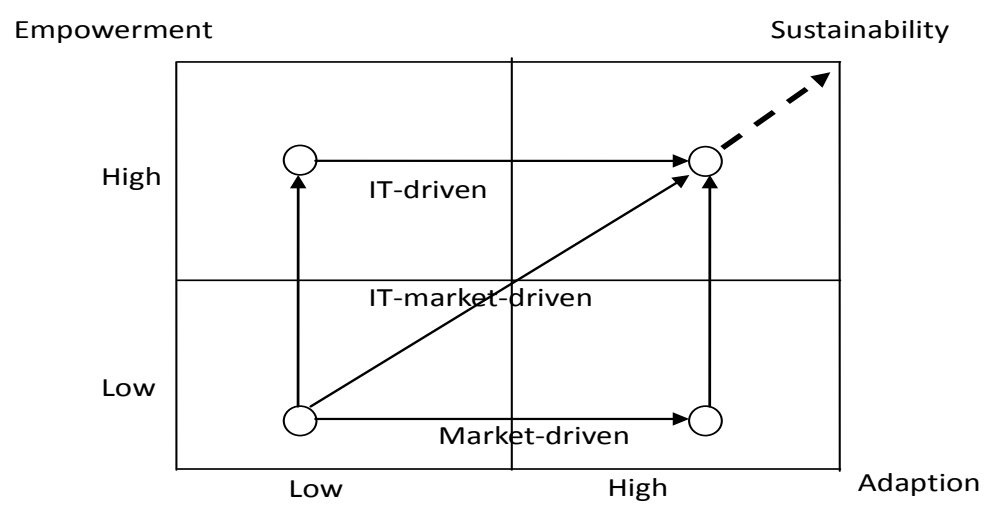

Figure 4. Three strategies for service system development.

\subsection{IT-Market-Driven Strategy}

An IT-market strategy means a platform using IT technology to support the management of a service network. In this situation, IT technology is a catalyst in the platform service system for achieving sustainability. 7-11 is a typical case for understanding an IT-market-driven strategy.

\subsection{Market-Driven Strategy}

The third strategy to sustainability is the market-driven strategy. This strategy means the platform service system is formed by a market mechanism. Like Hollywood, it largely depends on the market mechanism to build a cooperation network. Hollywood connected the demand side to the supply side through the main producers' coordination. It could move toward sustainability by the path of adaption-empowerment, but a lot of time is needed.

\section{Conclusions}

In this paper, the theoretical model argues applying the concept of platform to design a service system could improve service productivity. While the concept to manage a service system is used, three effects, empowerment, adaption, and sustainability, should occur. These effects are also a set of criteria to evaluate the level of how healthy a platform is. According to the three effects and cases, three basic development strategies are proposed. They are the IT-driven strategy, IT-market-driven strategy and market-driven strategy. Although these three strategies are alternatives to one another, it is believed that the IT-driven strategy is better than others in most situations.

The model can also assist academics and decision makers. For the academic research, a new concept for platform service system development and criteria for its management (i.e. empowerment, adaption, and sustainability) are proposed. It also suggests some future research directions. First, a new notion of platform service system and its theoretical foundation and process are given, but a substantial tool to realize the theoretical process and outcome is lacking. Second, a rigorous empirical study could make an emerging theory more solid and reliable. Third, exactly how a decision maker selects one of the platform service system development strategies is also an interesting research issue. For decision makers in a service industry, this model describes how the environmental conditions and processes work for higher service productivity.

\section{References}

[1] Sheehan, J. (2006) Understanding Service Sector Innovation, Communications of the ACM-Services Science, 49, $42-47$. http://dx.doi.org/10.1145/1139922.1139946

[2] Bridges, E. (2013) Editorial. The Service Industries Journal, 33, 1-5. http://dx.doi.org/10.1080/02642069.2013.746844

[3] Masso, J. and Vahter, P. (2012) The Link between Innovation and Productivity in Estonia's Service Sector. The Service Industries Journal, 32, 2527-2541. http://dx.doi.org/10.1080/02642069.2011.600444

[4] Gronroos, C. and Ojasalo, K. (2004) Service Productivity: Towards a Conceptualization of the Transformation of In- 
puts into Economic Results in Services. Journal of Business Research, 57, 414-423. http://dx.doi.org/10.1016/S0148-2963(02)00275-8

[5] Peppard, J. and Rylander, A. (2006) From Value Chain to Value Network: Insights for Mobile Operators. European Management Journal, 24, 128-141. http://dx.doi.org/10.1016/j.emj.2006.03.003

[6] Vargo, S.L. and Lusch, R.F. (2004) Evolving to a New Dominant Logic for Marketing. Journal of Marketing, 68, 1-17. http://dx.doi.org/10.1509/jmkg.68.1.1.24036

[7] Vargo, S.L. and Lusch, R.F. (2008) Service-Dominant Logic: Continuing the Evolution. Journal of the Academy of Marketing Science, 36, 1-10. http://dx.doi.org/10.1007/s11747-007-0069-6

[8] Rometty, G. (2008) Message from the Senior Vice President: Global Business Services: Service Science, Management, and Engineering. IBM Systems Journal, 47, 1-2. http://dx.doi.org/10.1147/sj.471.0002

[9] Hidaka, K. (2006) Trends in Service Science in Japan and Abroad. Quarterly Review, 19, 35-47.

[10] Spohrer, J., McDavid, D., Maglio, P.P. and Cordata, J.W. (2006) NBIC Convergence and Technology Coevolution: Towards a Services Science to Increase Productive Capacity. In: Bainbridge, W.S. and Roco, M.C., Eds., Managing Nano-Bio-Info-Cogno Innovations: Converging Technologies in Society, Springer, New York, 227-254.

[11] Vargo, S.L., Maglio, P.P. and Akaka, M.A. (2008) On Value and Value Co-creation: A Service Systems and Service Logic Perspective. European Management Journal, 26, 145-152. http://dx.doi.org/10.1016/j.emj.2008.04.003

[12] Edvardsson, B., et al. (2011) Does Service-Dominant Design Result in a Better Service System? Journal of Service Management, 22, 540-556. http://dx.doi.org/10.1108/09564231111155114

[13] Kwan, S.K. and Yuan, S.T. (2011) Customer-Driven Value Co-creation in Service Networks. In: Demirkan, H., et al., Eds., The Science of Service Systems, Service Science: Research and Innovations in the Service Economy, Springer Science+Business Media, LLC., 189-206. http://dx.doi.org/10.1007/978-1-4419-8270-4 11

[14] McLaughlin, C.P. and Coffey, S. (1990) Measuring Productivity in Service. International Journal of Service Industry Management, 1, 46-64. http://dx.doi.org/10.1108/09564239010002847

[15] Vuorinen, I., Jarvinen, R. and Lehtiene, U. (1998) Content and Measurement of Productivity in the Service Sector: AConceptualAnalysis with an Illustrative Case from the Insurance Business. International Journal of Service Industry Management, 9, 377-396. http://dx.doi.org/10.1108/09564239810228876

[16] Hornbrook, M.C. (1982) Hospital Case Mix: Its Definition, Measurement and Use: Part I. The Conceptual Framework. Medical Care Research and Review, 39, 1-42. http://dx.doi.org/10.1177/107755878203900101

[17] Gielnik, M.M., Frese, M., Graf, J.M. and Kampschulte, A. (2012) Creativity in the Opportunity Identification Process and the Moderating Effect of Diversity of Information. Journal of Business Venturing, 27, 559-576. http://dx.doi.org/10.1016/j.jbusvent.2011.10.003

[18] Filiatrault, P., Harvey, J. and Chebat, J.C. (1996) Service Quality and Service Productivity Management Practices. Industrial Marketing Management, 25, 243-255.

[19] Maglio, P.P., Srinivasan, S., Kreulen, J.T. and Spohrer, J. (2006) Service Systems, Service Scientists, SSME, and Innovation. Communications of the ACM, 49, 81-85. http://dx.doi.org/10.1145/1139922.1139955

[20] Porter, M. (1980) Competitive Strategy: Techniques for Analyzing Industries and Competitors. Free Press, New York.

[21] Porter, M. (1985) Competitive Advantage: Creating and Sustaining Superior Performance. Free Press, New York.

[22] Normann, R. and Ramirez, R. (1994) Designing Interactive Strategy: From the Value Chain to the Value Constellation. John Wiley \& Sons, Chichester.

[23] Tapscott, D., Ticoll, D. and Lowy, A. (2000) Digital Capital: Harnessing the Power of Business Webs. Harvard Business School Press, Boston.

[24] Achrol, R. and Kotler, P. (1999) Marketing in Network Economy. Journal of Marketing, 63, 146-163. http://dx.doi.org/10.2307/1252108

[25] Tomlinson, P.R. (2012) Industry Institutions, Social Capital, and Firm Participation in Industrial Development. Industrial and Corporate Change, 21, 1-29. http://dx.doi.org/10.1093/icc/dtr028

[26] Madhavan, R., Koka, B. and Prescott, J.E. (1998) Networks in Transition: How Industry Events Shape Interfirm Relationships. Strategic Management Journal, 19, 439-459. http://dx.doi.org/10.1002/(SICI)1097-0266(199805)19:5<439::AID-DIA952>3.0.CO;2-2

[27] Spohrer, J. and Maglio, P.P. (2007) The Emergence of Service Science: Toward Systematic Service Innovations to Accelerate Co-Creation of Value. Production and Operations Management, 17, 238-246. http://dx.doi.org/10.3401/poms.1080.0027

[28] Normann, R. (2001) Reframing Business: When the Map Changes the Landscape. Wiley, Chichester.

[29] Epstein, E.J. (2006) The Big Picture: Money and Power in Hollywood. Random House Trade Paperbacks, New York. 
[30] Katz, M.L. and Shapiro, C. (1994) Systems Competition and Network Effects. Journal of Economic Perspectives, 8, 93-115. http://dx.doi.org/10.1257/jep.8.2.93

[31] Stabell, C.B. and Fjeldstad, O.D. (1998) Configuring Value for Competitive Advantage: On Chains, Shops, and Networks. Strategic Management Journal, 19, 413-437. http://dx.doi.org/10.1002/(SICI)1097-0266(199805)19:5<413::AID-SMJ946>3.0.CO;2-C

[32] Hall, R. (2006) A Framework Linking Intangible Resources and Capabilities to Sustainable Competitive Advantage. Strategic Management Journal, 14, 607-618. http://dx.doi.org/10.1002/smj.4250140804

[33] Helfat, C.E. and Peteraf, M.A. (2003) The Dynamic Resource-Based View: Capability Lifecycles. Strategic Management Journal, 24, 997-1010. http://dx.doi.org/10.1002/smj.332

[34] Allee, V. (2000) Reconfiguring the Value Network. Journal of Business Strategy, 21, 1-6.

[35] Zairi, M. (1992) The Art of Benchmarking: Using Customer Feedback to Establish a Performance Gap. Total Quality Management, 3, 177-188. http://dx.doi.org/10.1080/09544129200000019

[36] Shane, S. (2000) Prior Knowledge and the Discovery of Entrepreneurial Opportunities. Organization Science, 11, 448469. http://dx.doi.org/10.1287/orsc.11.4.448.14602

[37] Daft, R.L. and Weick, K.E. (1984) Toward a Model of Organizations as Interpretation Systems. Academy of Management Review, 9, 284-295. http://dx.doi.org/10.5465/AMR.1984.4277657

[38] Pfeffer, J. and Salancik, G.R. (1978) The External Control of Organizations. Harper \& Row, New York.

[39] Chu, K.F. (2003) An Organizational Culture and the Empowerment for Change in SMEs in the Hong Kong Manufacturing Industry. Journal of Materials Processing Technology, 139, 505-509. http://dx.doi.org/10.1016/S0924-0136(03)00527-2

[40] Miles, R.E., Snow, C.C., Meyer, A.D. and Coleman, H.J. (1978) Organizational Strategy, Structure, and Process. The Academy of Management Review, 3, 546-562. http://dx.doi.org/10.5465/AMR.1978.4305755

[41] Kickul, J. and Gundry, L.K. (2002) Prospecting for Strategic Advantage: The Proactive Entrepreneurial Personality and Small Firm Innovation. Journal of Small Business Management, 40, 85-97. http://dx.doi.org/10.1111/1540-627X.00042

[42] Javidan, M. (1998) Core Competence: What Does It Mean in Practice? Long Range Planning, 31, 60-71. http://dx.doi.org/10.1016/S0024-6301(97)00091-5

[43] Synnott, W.R. and Gruber, W.G. (1981) Information Resource Management: Opportunities and Strategies for the 1980s. John Wiley \& Sons, Inc., New York.

[44] Huggins, R. and Johnston, A. (2009) Knowledge Network in an Uncompetitive Region: SME Innovation and Growth. Growth and Change, 40, 227-259. http://dx.doi.org/10.1111/j.1468-2257.2009.00474.X

[45] Lin, Y.Y. and Zhang, J. (2005) Changing Structures of SME Networks: Lessons from the Publishing Industry in Taiwan. Long Range Planning, 38, 145-162. http://dx.doi.org/10.1016/j.lrp.2005.02.007

[46] Lusch, R.F., Vargo, S.L. and O’Brien, M. (2007) Competing through Service: Insights from Service-Dominant Logic. Journal of Retailing, 83, 5-18. http://dx.doi.org/10.1016/j.jretai.2006.10.002

[47] Forlani, D. and Mullins, J.W. (2000) Perceived Risks and Choices in Entrepreneurs’ New Venture Decisions. Journal of Business Venturing, 15, 305-322. http://dx.doi.org/10.1016/S0883-9026(98)00017-2

[48] Bolton, P. and Dewatripont, M. (1994) The Firm as a Communication Network. Quarterly Journal of Economics, 109, 809-839. http://dx.doi.org/10.2307/2118349

[49] Coase, R.H. (1937) The Nature of the Firm. Economica, 4, 386-405. http://dx.doi.org/10.1111/j.1468-0335.1937.tb00002.x

[50] Rese, M. (2006) Successful and Sustainable Business Partnerships: How to Select the Right Partners. Industrial Marketing Management, 35, 72-82. http://dx.doi.org/10.1016/j.indmarman.2005.08.009

[51] Voces, R., Diaz-Balteiro, L. and Romero, C. (2012) Characterization and Explanation of the Sustainability of the European Wood Manufacturing Industries: A Quantitative Approach. Expert Systems with Applications, 39, 6618-6627. http://dx.doi.org/10.1016/j.eswa.2011.12.040

[52] Labuschagne, C., Brent, A.C. and van Erck, R.P.G. (2005) Assessing the Sustainability Performances of Industries. Journal of Cleaner Production, 13, 373-385. http://dx.doi.org/10.1016/j.jclepro.2003.10.007

[53] Kuo, N.W., Hsiao, T.Y. and Lan, C.F. (2005) Tourism Management and Industrial Ecology: A Case Study of Food Service in Taiwan. Tourism Management, 26, 503-508. http://dx.doi.org/10.1016/j.tourman.2004.02.015

[54] Dobusch, L. and Schubler, E. (2013) Theorizing Path Dependence: A Review of Positive Feedback Mechanisms in Technology Markets, Regional Clusters, and Organizations. Industrial and Corporate Change, 22, 617-647. http://dx.doi.org/10.1093/icc/dts029 
[55] Blanchard, P., Huiban, J.P., Musolesi, A. and Sevestre, P. (2013) Where There Is a Will, There Is a Way? Assessing the Impact of Obstacles to Innovation. Industrial and Corporate Change, 22, 679-710. http://dx.doi.org/10.1093/icc/dts027

[56] Jalaladdini, S. and Oktay, D. (2011) Urban Public Spaces and Vitality: A Socio-Spatial Analysis in the Streets of Cypriot Towns. Procedia-Social and Behavioral Sciences, 35, 664-674. http://dx.doi.org/10.1016/j.sbspro.2012.02.135

[57] Gnyawali, D.R. and Srivastava, M.K. (2013) Complementary Effects of Clusters and Networks on Firm Innovation: A Conceptual Model. Journal of Engineering and Technology Management, 30, 1-20. http://dx.doi.org/10.1016/j.jengtecman.2012.11.001

[58] Pirages, D. (2000) Diversity and Social Progress in the Next Millennium: An Evolutionary Perspective. Futures, 32, 513-523. http://dx.doi.org/10.1016/S0016-3287(00)00004-5

[59] Simon, H.A. (1997) Models of Bounded Rationality: Empirically Grounded Economic Reason. MIT Press, Cambridge. 